\title{
Institutional determinants of R\&D investment: Evidence from emerging markets
}

\begin{abstract}
Institutional environment of a country plays an important role for innovation activities. Our results confirm that external environment of emerging countries influence the $R \& D$ investment. Using Generalized Method of Moments (GMM) estimation of panel data for 664 firms from selected 20 emerging markets during the period of 2006-2013, we find that institutional quality has significant impact on R\&D investment. The results show that government effectiveness, rule of law, and regularity quality have positive impact, while corruption and political instability have negative impact on $R \& D$ investment in the emerging markets. We also performed elasticity test to compare among the institutional factors. The results show that among the institutional determinants, corruption of a particular emerging country is found to be most important in influencing $R \& D$ investment followed by regularity quality, government effectiveness, rule of law, and political instability. These results would be helpful to investors and policy makers to assess the requirements of sustainable development. The results of this study clearly demonstrate that to attract more R\&D investment as a source of sustainable development, government should ensure a sound and stable institutional environment along with strengthening other firm level factors as institutional factors are more important to explain the variation over the time and also cost effective in terms of implementation.
\end{abstract}

Key Words: Institutional settings, Determinants, R\&D investment, Emerging markets, GMM estimation

\section{Introduction}

Research and Development (R\&D) investment is considered to be one of the most essential elements in promoting economic growth and development (Alam et al., 2017). Wang (2010) observed that countries with sufficient level of R\&D investment can achieve target economic growth by promoting productivity and advancing their knowledge base. A central focus of innovation research is the analysis of R\&D determinants (Barge-Gil and López, 2014). Previous research has used the Schumpeterian hypothesis and inter-industry effects to explain the determinants of R\&D investment (Barge-Gil and López, 2014). Resource based view (Lai et al., 2015) and the behavioural view (Lewellyn and Bao, 2015) have also been used to 
explain the determinants of R\&D investments. However, Wang (2010) stated that institutional factors may also help to explain R\&D investment. Better institutional environment may stimulate R\&D activity by providing enhanced collaborative capacity to the firms (Wu et al., 2016). Similarly, Srholec (2011) stated that attributes of the firm as well as the institutional settings within which firms operate do matter for innovation. Wang et al. (2015) supported this notion and indicated that R\&D investment strategy, structure and process must be compatible with institutional demands. There are several reasons why the institutional environmentis considered to be most important drivers for innovative activities. First, as risky and long-term investment, $R \& D$ investment is affected by agency problem. However, improved institutions help to reduce the agency problem among decision makers and thereby help to increase the R\&D investment (Choi et al., 2014). Second, the quality of institution increases the R\&D investment by enabling firms to get access to various factors and innovation intermediaries (Wu et al., 2016). Third, good institutional quality may attract foreign investors (Bénassy-Quéré, 2007), helps firms to access external finance (La Porta et al.,1997), mitigate opaque information (Hillier et al., 2011), and provides incentives to the firms (Edquist and Johnson, 1997) and therefore, promotes R\&D investment within the firms. Fourth, institutions influence the transaction cost of innovation (Wang et al., 2015). Poor institutions such as corruption may increase the R\&D investment cost. Fifth, good governance such as strong intellectual property rights (IPRs) provide investors protections, thereby, facilitates investment in R\&D (Krammer, 2015). In this regard, Ghosh and $\mathrm{He}$ (2015) stated that stronger investor protection reduces the manager's opportunistic behaviour to divert cash flow to them, therefore, more resources employed to value enhancing capital project like R\&D. Moreover, Xiao (2013) stated that legal protection to shareholders reduces the agency conflict and solve the under and over investment problem of R\&D activities. Sixth, strong institutions ensure the return from uncertain investment like R\&D by managing 
risk (Edquist and Johnson, 1997) and fostering an innovation-friendly environment (Krammer, 2015). Finally, institutions have decisive influence on nature and extent of R\&D investment (Hashi and Stojcic, 2013). Considering the huge importance of institutional factors in determining the extent of R\&D investment, this paper has made an effort to explore the institutional determinants of $R \& D$ activities.

Although institutional framework shapes up strategic investment decisions all around the world, this issue is even more critical for emerging economies. Peng et al. (2008) and Meyer et al. (2009) pointed out that institutional framework is more sensitive to firms' investment decisions and performance in emerging economies. Peng et al. (2008) suggested that institutional condition in emerging economies constitute the third leg of strategy tripod along with industry and firm level condition to shape up organisational strategy and performance. Therefore, R\&D investment as an important part of overall firm strategic investment should consider institutional condition. R\&D investment is growing faster in emerging economies in recent years. Li and Kozhikode (2009) stated that global R\&D landscape is changing very fast and emerging markets are attracting more attention from multinational companies (MNCs) as a location for increased level of $\mathrm{R} \& \mathrm{D}$ investment due to higher demand, lower cost and increased level of technology adoption. Logue (2011) stated that the rate of return from the same investment is higher in emerging markets than in developed ones. Emerging countries are considered as land of profitable opportunities to the foreign investors (Phylaktis, 2009). As a result, in recent years, MNCs are establishing large number of R\&D centres in emerging markets (Patra and Krishna, 2015). Kafouros and Aliyev (2016) stated that better institutional settings offer competitive advantages to the firms by reducing transaction costs and increasing the convenience of contract enforcement process. Accordingly, emerging economies are constantly improving their institutional quality (OECD, 2011; Kafouros and Aliyev, 2016). Therefore, it would be interesting to see if the institutional environment in the 
emerging countries has any impact of $R \& D$ investment. Although institutions have been identified as a core determinant of investment in general and R\&D investment in particular, there is a lack of research examining the relationship between institutional factors and $R \& D$ investment. The paper is motivated by the findings from Wang (2010) and Pattit et al. (2012) who pointed out that institutional factors may better explain the R\&D activities and also from the observation by Barge-Gil and López (2014), who pointed out the omission of important factors that determine the R\&D activities.Moreover, Choi et al. (2014) stated that firms in emerging markets are trying to become more competitive by relying on innovation more than any other business strategy. However, Choi et al. (2014) pointed out that there is very limited evidence available on how institutions may have effect on innovation activities by emerging market firms. The use of institutional theory in explaining the R\&D investment is more appropriate than using other firm level theory. For example, Pattit et al. (2012) mentioned that institutional theory helps to explain the larger aggregate trends from period to period whereas firm-level theories only explains some variance within the period.

This paper contributes to the literature in several ways. First, we investigate the institutional determinants of R\&D spending for 3973 firm-year observations from selected 20 emerging markets during the period of 2006-2013. The earlier researchers have emphasized on single factors such as legal institutions (Anderlini et al., 2013; Seitz and Watzinger, 2017); political instability and education system (Varsakelis, 2006); government effectiveness (Dolfsma and Seo, 2013); regulations (Blind, 2012; Blind et al., 2017). Therefore, these studies are not sufficient to understand the impact of institutional factors on $R \& D$ investment from the context of emerging markets. To fill this gap, this paper has taken a holistic approach and considers various aspects of institutions and attempt to identify the social, legal and political institutional determinants of $\mathrm{R} \& \mathrm{D}$ investment from the context of emerging markets. By doing this, the study provides significant insights into the importance of external 
environments, in particular institutional settings for $R \& D$ investment in the emerging markets. This is important as Mahmood et al. (2012) pointed out that innovation is mostly influenced by the interaction between firm and its external environment. Second, unlike earlier research on institutional determinants of $R \& D$ investment, this paper has taken a holistic approach and used a large set of institutional factors to examine their influence on R\&D intensity. This has given the opportunity to examine the relative importance of those factors in affecting $R \& D$ investment. This paper has calculated elasticity of each institutional determinant to identify the relative importance. Finally, exploring the institutional determinants of $R \& D$ investment in emerging markets is important. Returns from $R \& D$ investment in the emerging countries are higher than those of advanced countries (Lederman and Maloney, 2003) and therefore attract more investments in R\&D. However, lack of knowledge on institutional determinants in those countries might put investors at risk. Peng et al. (2008) also emphasised on further research in the area of institutional condition of emerging markets as this would benefit both the home country managers and managers of firms from abroad that are willing to enter into the emerging market as part of their expansion strategy.

The paper is organized as follows: the next section presents a brief theoretical discussion and develops the hypotheses. Section three introduces the data and research method. Section four presents result and discussions. The last section concludes the study and highlights some policy implications of the study.

\section{Theory and Hypotheses}

Institutional theory posits that institutional settings of a country facilitates investment by providing incentives and supports, creating a stable environment, mitigating transaction costs, reducing risk and uncertainty. North (1990) and Daude and Stein (2007) pointed out that investment decision may depend on different dimensions of institutional environment. $R \& D$ 
activities as a form of investment is also sensitive to institutional quality (Waarden, 2001). In this regard, Varsakelis (2006) and Krammer (2009) stated that investment in education, strong legal protection, stable political and economic situation are positively related with technological performance. Pattit et al. (2012) found evidence in support of the influence of institutions on technological development in the US since the mid-19 ${ }^{\text {th }}$ century. Both the formal and informal institutions played a dominant role in shaping up the US technological change over a considerably longer period of time. Wang et al. (2015) mentioned that innovation activities of firm can be influenced by institutions through laws, regulations and policies. It has been mentioned further that institutions influence the cost of innovation inputs and also protects the innovation outputs and thereby influence the firms' innovation activities. Choi et al. (2014) pointed out that effective institutions can encourage the R\&D investments by minimising the agency problem among the decision makers. Better institutions promote financial market liberalisation which in effect encourages $R \& D$ investment by reducing financial constraints of the firms (Laeven, 2003). Therefore, it is highly likely that stronger institutional settings help to foster R\&D investment and improve knowledge accumulation and knowledge spillover in a country. These tend to confirm the notion that firms' innovation capabilities depend on institutional settings (Priem and Butler, 2001; Yi et al., 2013).

There may be huge disparities in features of institutions. According to Krammer (2015), "In practice, measuring institutions is a daunting task". In this regard, Mahendra et al. (2015) stated that it is difficult to measure institutional variables as each country and region may have different understanding and perceptions on what institutions are. Dunning (2006) has also pointed out the differences in country level institutional variables. Country level institutions have impact on firm strategy (Wan and Hoskisson, 2003). Pindado et al. (2015) 
found evidence that country level institutions strongly affect the market valuation of the firm R\&D investment. Among the country level factors, financial system, education system, public policy and training system are important institutional factors for national innovation systems (Freeman, 1987; Dosi et al., 1990; Lundvall, 1992). In this paper, we have used institutional variables based on the suggestions by Kaufmann et al. (2009) and Krammer (2015). These are government effectiveness, rule of law, corruption, political system and regularity quality. Although, institutional setting of a country may also include various other cognitive and normative elements as suggested by North (1990), the selected variables are more tangible than others.

Government effectiveness has an impact on firm performance through its effect on managerial assumption and actions (Pearce et al.,2011), therefore, it reduces the agency cost. The lower agency cost increases the likelihood of efficient investment. Moreover, an effective government makes investors to feel confident and safeguards future returns from investment. In a relevant study, Jiao et al. (2015) pointed out that fiscal policies set out by the government provides internal incentives to the firm and promote entrepreneurial activities. Effective government encourages private and public firms to engage in $R \& D$ investment. For example, Singapore government promotes R\&D investment in both private and public firms by arranging training for $\mathrm{R} \& \mathrm{D}$ manpower and attracting foreign investors (Tsang et al., 2008). In an empirical study, Mahmood and Rufin (2005) stated that active role of government accelerates the technological innovation through spillover effect and by creating networks between firms and individuals. Moreover, greater government capacity may promote R\&D investment by providing greater support, budgets and subsidies for creative and innovative activities. In a recent paper, Szczygielski et al. (2017) found evidence that efficiency of government efforts seems to contribute to better innovation performance by 
firms in emerging markets such as Turkey and Poland. As the role of government tends to be much more influential in emerging markets (Hong et al., 2015), this study is proposing the following hypothesis:

Hypothesis 1: There will be a positive relationship between Government effectiveness and $R \& D$ investment.

Rule of law measures the judicial strength of a country (Wan and Hoskisson, 2003) and ensures strict enforcement of law. Rule of law or a strong legal system seems to be important in encouraging R\&D investment (Seitz and Watzinger, 2017). La Porta et al. (1997) provided evidence that strong rule of law helps to develop financial market and therefore help to support R\&D investment. A developed and liquid financial market ensures access to capital at a lower cost and reduces information asymmetry. Moreover, strong rule of law helps to reduce managerial expropriation, protects patent right and ensures contract enforcement (Seitz and Watzinger, 2017). All these benefits arising out of strong rule of law help to increase R\&D investment by reducing the riskiness of the same. Acharya and Subramanian (2009) stated that creditors' right and employee right also help to encourage R\&D. The authors have argued that strong creditors' right helps protect the creditors from bankruptcy fear and encourage more investment in R\&D. Similarly, employee right helps to encourage employees to devote more time to innovation activities despite the possibility of failure at the end. Seitz and Watzinger (2017) have shown that the higher R\&D investment in Germany compared to Italy is due to its superior rule of law and strict contract enforcement. Moreover, Pindado et al. (2015) confirm that strong legal system enhances R\&D by improving investors' protection and confidence. Similarly, using institutional theory, Furukawa (2007) confirmed that stronger rule of law provide strong protection of patent rights and investment incentives that motivate the investors in R\&D activity. However, in some cases, tight laws may discourage innovative activities. The basic argument is that strict law would increase the 
compliance cost and therefore, firms feel discouraged to raise external capital which in turn reduces the corporate investment such as R\&D investment (Blind, 2012). On the other hand, Waarden (2001) stated that de-regulation may encourage innovation as it provides more freedom to innovate and concluded that the relationship between law and innovation is not straightforward. Although, evidence on the relationship between rule of law and $R \& D$ activities has been found to be positive or complicated in some cases, we still do not have enough evidence for emerging markets as most of those studies are based on developed markets. However, in a recent paper, Jiao et al. (2015) found a positive relation between legal environment and innovation based on an emerging market. Thus, following Jiao et al. (2015), this study is proposing the following hypothesis:

\section{Hypothesis 2: Rule of law and $R \& D$ investment are positively correlated.}

Corruption, as an institutional void, profoundly influence the level of R\&D investment. Rodriguez et al. (2005) defined corruption as abuse of public power for private benefit. Anokhin and Schulze (2009) argued that corruption undermines the foundation of institutional trust that is essential for investment in innovative activities. Corruption increases the cost of investment, as investors need to pay bribes to the officials to obtain the permits and licenses (Daude and Stein, 2007). Romer (1994) added that by increasing the cost of fixed investment, corruption reduce the entry of new goods and technology. Moreover, it is highly likely that corruption makes the project uncertain and less profitable. Consequently, both local and foreign investors become demotivated to long-term and costly investment like R\&D. Thus, Anokhin and Schulze (2009) stated that corruption hinders the productivity, entrepreneurship, and investment in R\&D. The authors have argued that corruption increases agency and transaction costs, limits revenues and erodes the potential value of the returns of the opportunity. In a similar vein, Javorcik and Wei (2009) stated that high level of corruption increases information asymmetry and cost of doing business. Therefore, it is 
highly likely that in the presence of corruption, $R \& D$ investment becomes riskier and return from $R \& D$ investment would be lower. Therefore, firms in countries with high level of corruption would find it discouraging to make investment in innovation activities. As corruption remain major problems of doing business and innovation for most of the emerging countries (IFC, 2002), this study is proposing the following hypothesis:

\section{Hypothesis 3: The presence of corruption negatively affects the level of $R \& D$ investment.}

Political condition of any country has significant impact on corporate investment. Political stability is conducive to favourable investment environment as stability ensures continuation of economic policies and reduction of future uncertainty. R\&D investment as a form of corporate investment is also influenced by political condition. R\&D investment is long term and risky in nature. Therefore, any instability in political condition will affect R\&D more than other forms of corporate investments. Masino (2015) pointed out that in an uncertain and volatile economy, firms tend to reduce the level of investment in innovative activities. Atanassov et al. (2016) argued that uncertainty increases the value of option to wait before making investments. The authors have pointed out that R\&D investment is most appropriate example of investment with extreme irreversibility and high adjustment cost. Therefore, in the face of any uncertainty, option to wait would be more valuable than investing in $R \& D$ amid high uncertainty. This will eventually lead to lower R\&D investment when economy becomes volatile and faces high uncertainty. Political instability is the major cause of economic uncertainty as suggested by Mobarak (2005) and Klomp and Haan (2009). Politics influence the shape of government policy to stimulate investment in the short-run and formulate economic and regulatory policy in the long run (Julio and Yook, 2012). Instability in the political condition gives rise to the possibility of frequent changes or cancellation of those short and long run policies and creates economic uncertainty and therefore affect the R\&D investment. A number of authors have found that political instability negatively affects 
the level of R\&D investment including Henisz (2002), Allard et al. (2012), and Masino (2015). As the volatility and uncertainty caused by political uncertainty are significantly higher in emerging markets as suggested by Easterly et al. (2000) and Klomp and Haan (2009), this study is proposing following hypothesis:

Hypothesis 4: R\&D investment is negatively related to political instability.

Jalilian et al. (2007) pointed out that effective regulations help to achieve social objectives set by governments for regulatory authorities, enabling social goals to be achieved at minimum cost. On the other hand, inefficient and inconsistent government regulations lead to uncertainly for investors as it raises the investment cost (Parker, 1999). Good regulatory quality helps firms with market entry and keeping up-to-date with developments. Moreover, good quality of regulations increases the investment opportunities of a country. In this regards, Kirkpatrick et al. (2006) concluded that the quality of regulatory framework and foreign investment is highly related. They also observed that due to weak government regulations foreign investors may reluctant to investment in the large investment projects like R\&D. Similarly, Mahendra et al. (2015) found evidence that good regulatory quality and access to finance have positive impact on innovation. Although, Blind et al. (2017) stated that the relation between regulations and innovation may differ due to market environments, they found that regulations have positive influence on innovation in low uncertain markets while opposite effects in high uncertain markets. Thus, due to the variation in quality of regulations and market environments among the emerging countries, the relation may vary. However, as emerging markets are improving the quality of government regulations, the following hypothesis is postulated:

Hypothesis 5: Regularity Quality is positively correlated with $R \& D$ Investment. 
In addition to the above, other factors also affect firms' R\&D investment. Scott (1995) and Oliver (1997) stated that strategic choices such as R\&D spending are driven by institutional frameworks, along with industry conditions and firm-specific resources. Firm size (Lall, 1983), cash flow (Bhagat and Welch, 1995), debt ratio (Hall, 1992) and GDP growth (Wang, 2010) are among those important variables that may affect $R \& D$ investment decisions. Larger firms tend to be more diversified, more technologically complex and better aware of technological opportunities (Lall, 1983). Pecking order theory and internal fund theory argue that financial status, measured by the cash flow of a firm, determines the level of investment. Bhagat and Welch (1995) noted that R\&D occurs mostly when firms have more operating cash flows on hand and are thus able to avoid the costs of external capital markets. According to Hall (1992), external finance, and specifically debt, is not favoured as a form of finance for R\&D investment, as debt servicing usually requires a stable source of cash flow, which makes it more difficult to find funds for R\&D investment. Increased GDP growth seems to be allocated to increased investment in R\&D. Wang (2010) pointed out that GDP growth creates stronger incentives for R\&D investment.

\section{Methodology}

\subsection{Data}

To test the hypothesis, data were collected from several sources, including DataStream, World Bank's Development Indicators (WDI) and Worldwide Governance Indictor (WGI), World Bank. Firm level data such as R\&D expenditure, sales, total assets, total debt, cash flow, and industry type were drawn from the DataStream. GDP growth data were obtained 
from WDI. Data on institutional factors, measuring government effectiveness, regularity quality, rule of law, corruption, and political stability were obtained from $\mathrm{WGI}^{1}$, World Bank.

The eight-year sample period of the study was from 2006 to 2013. The post-reform period of R\&D reporting was considered so that the sample firms would treat $R \& D$ expenditure homogeneously. Moreover, gaps in the latest data were minimised where possible. We applied several sample selection criteria. First, in order to be included in the sample, firms must have at least five consecutive years of data between 2006 and 2013 to control the short panel bias (see Flannery and Hankins, 2013). Moreover, this requirement is necessary to test the assumption of generalized method of moments (GMM) estimation on the absence of second order auto-correlation AR(2) (Pindado et al., 2017). Second, Hong Kong, Singapore, South Korea and Taiwan were excluded, as these countries are now considered as emerged economies. Third, following Pindado et al. (2015), financial firms were also excluded due to their different corporate structure and strategy. After dropping missing values and unrealistic figures (such as negative values of R\&D expenditure), the sample consisted of 664 firms from 20 emerging countries ${ }^{2}$ (See Table 1). Several sources of data and in particular, missing values lead to unbalanced panel data. In a relevant study, Hillier et al. (2011) states that unbalanced panel data could control the survivorship bias problem.

Table 1: Sample by Country ${ }^{3}$

\begin{tabular}{|c|c|c|c|c|c|}
\hline$\overline{\text { Country }}$ & Frequency & $\begin{array}{c}\text { Composition } \\
(\%)\end{array}$ & Country & Frequency & $\begin{array}{c}\text { Composition } \\
(\%)\end{array}$ \\
\hline
\end{tabular}

\footnotetext{
${ }^{1}$ Data on institutional variables are accessed from WGI, World Bank and produced by Kaufmann and Kraay. Please refer to the following website: (http://info.worldbank.org/governance/wgi/\#home).

${ }^{2}$ The list of emerging markets may vary from one organisation to another. To avoid this problem, all emerging markets from all organisations' lists (IMF, Goldman Sachs, FTSE, MSCI, The Economist, S\&P, Dow Jones, BBVA and Columbia University EMGP - 2013) were selected for this study.

${ }^{3}$ To mitigate the potential bias from the dominant country in the sample, we ran separate regression except India which is consists of $41.27 \%$ of sample. We find similar results of main regression. This implies that although India has dominating sample, it has same behavioural characterises like other emerging markets. The results will provide upon request. The unobserved heterogeneity of the countries such as Bangladesh, Greece, Israel, \& Pakistan can be controlled by applying generalized method of moments of panel data.
} 


\begin{tabular}{|c|c|c|c|c|c|}
\hline Bangladesh & 2 & 0.301 & Malaysia & 34 & 5.120 \\
\hline Brazil & 9 & 1.355 & Pakistan & 12 & 1.807 \\
\hline Chile & 2 & 0.301 & Philippine & 11 & 1.657 \\
\hline China & 60 & 9.036 & Poland & 4 & 0.602 \\
\hline Egypt & 2 & 0.301 & Romania & 1 & 0.151 \\
\hline Greece & 37 & 5.572 & Russia & 12 & 1.807 \\
\hline India & 274 & 41.27 & Saudi Arabia & 2 & 0.301 \\
\hline Indonesia & 17 & 2.560 & South Africa & 28 & 4.217 \\
\hline Israel & 59 & 8.886 & Sri Lanka & 6 & 0.904 \\
\hline Jordan & 5 & 0.753 & Turkey & 87 & 13.102 \\
\hline
\end{tabular}

Table- 2 displays the definition of the variables. All variables are standardized to a common USD exchange rate. Some of the explanatory variables have higher scales than others and high absolute value of the variables increases the heteroscedasticity presence (Grabowski, 1968). In order to avoid these problems natural logarithm, ratio and percentage of the variables were used. Government effectiveness, rule of law, control of corruption, political instability, and regulatory quality are considered as institutional variables following Kaufmann et al. $(2009 ; 2010)$ and Krammer (2015). The indices range from -2.5 to 2.5 (approximately), with higher values indicating stronger institutions. These indices are based on over 30 different data sources produced by a variety of survey institutions, think tanks, non-governmental organizations, international organizations and private sector firms (Kaufmann et al., 2010). They applied statistical tool known as unobserved components model (UCM) to combine the many individual data sources into aggregate indicators. Although these variables are measured as aggregate value, they are time variant as financial data. 
Table 2: Definitions of Variables

\begin{tabular}{lll}
\hline \hline Variables & Variable definitions (measurement) & Sources \\
\hline R\&D intensity & R\&D expenditure over sales & DataStream \\
Government effectiveness & Measures of competency or capacity of the government. & World Bank (WGI) \\
Rule of law & Measures the judicial strength & World Bank (WGI) \\
Corruption & Measures the misuse of power & World Bank (WGI) \\
Political instability & Measures the likelihood of political instability & World Bank (WGI) \\
Regularity quality & Captures the ability of the government to promote development & World Bank (WGI) \\
Firm size & Firm size is measured by total asset & DataStream \\
Cash flow & The ratio of cash flows to sales & DataStream \\
Debt ratio & The ratio of total debt over total assets & DataStream \\
GDP growth & Annual GDP growth of a country & World Bank (WDI) \\
Industry type & The Industry takes value 1 if it is technology intensive; 0 otherwise & DataStream \\
\hline \hline
\end{tabular}

\footnotetext{
${ }^{4}$ OECD two-digits SIC codes: 28,35,36,37,38,48,73 and 87 were considered as technology intensive industry following Kallunki et al. (2009).
} 
Table-3 presents descriptive statistics for the variables. Government effectiveness has a mean of 0.23220 and a range of -0.89306 (for Egypt) and 1.36792 (for Israel). This implies that Israel has effective government while Egypt has poor government effectiveness. Rule of law has a mean of 0.06717 and a range between -0.97680 (for Pakistan) and 1.36679 (for Chile) which indicates that Chile has stronger rule of law while Pakistan has poor legal system. The mean value (negative) of corruption is -0.21205 which indicates that emerging countries still suffer from a lack of control of corruption. The minimum value $(-1.42297)$ corresponds to Bangladesh which indicates poor control of corruption and maximum value (1.56205) corresponds to Chile which implies strong control of corruption. In terms of regularity quality, Chile (1.54042) has stronger regularity quality while Bangladesh (-0.96320) has poorer that than others. Political instability has a mean of -0.91154 and a politically instable country is Pakistan (-2.81208) while politically stable country is Poland (1.05695). The results show that some emerging countries have stronger institutional settings than others. For example, Chile has stronger rule of law, lesser corruption and good regularity quality while Israel has effective government and Poland has stable political condition. On the other hand, Egypt has weaker government effectiveness and Pakistan has greater political instability, and Bangladesh has poorer regularity quality and higher levels of corruption than any other emerging countries. These show that institutional factors such as government effectiveness, rule of law, corruption, political instability and regulatory quality vary among emerging markets.

Among the control variables, firm size has a mean of 5.38384 and a range of 3.26553 (for Sri Lanka) and 8.64330 (for Russia). Firm size varies among emerging countries because some, such as Brazil, Russia, India and China (BRIC), have more MNCs than others. The mean 
value of cash flows is9.94017 and a highest value correspond to 122.0180 (for Turkey) and lowest value corresponds to -685.430 (for India). GDP growth has a mean of 5.54712 and a range between -8.87000 (for Greece) and 14.1600 (for China). These results indicate that cash flows and GDP growth also vary among emerging markets. This is because the impact of the recent global financial crisis 2007-2010 was not the same for all countries and firms. Moreover, EURO crisis could cause this variation among the emerging countries during the observed period. Industry dummy has a mean of 0.62973 which indicates that $62.97 \%$ of the sample is from technology intensive industry. Tabrizi (2005) points out that technology intensive industry spend more on R\&D than others. In general, technology-based firms place more weight on bringing new knowledge to the markets, advancing technology, and increasing employee skills, internal competencies and capabilities. These results support considering control of the industry effect in the model.

Table 3: Summary Statistics

\begin{tabular}{|c|c|c|c|c|}
\hline Variable & Mean & Standard Deviation & Minimum & Maximum \\
\hline $\mathrm{R} \& \mathrm{D}$ intensity & 0.00750 & 0.01889 & 0.00000 & 0.25229 \\
\hline Government effectiveness & 0.23220 & 0.47705 & -0.89306 & 1.36792 \\
\hline Rule of law & 0.06717 & 0.41920 & -0.97680 & 1.36679 \\
\hline Corruption & -0.21205 & 0.45953 & -1.42297 & 1.56205 \\
\hline Political stability & -0.91154 & 0.56635 & -2.81208 & 1.05695 \\
\hline Regularity quality & 0.05404 & 0.52521 & -0.96320 & 1.54042 \\
\hline Firm size & 5.38384 & 0.85824 & 3.26553 & 8.64330 \\
\hline Cash flow & 9.94017 & 19.30518 & -685.430 & 122.180 \\
\hline Debt ratio & 0.25180 & 0.18132 & 0.00000 & 0.88221 \\
\hline GDP growth & 5.54712 & 3.97904 & -8.87000 & 14.1600 \\
\hline Industry dummy & 0.62973 & 0.48293 & 0.00000 & 1.00000 \\
\hline
\end{tabular}

Source: Author's Calculation 


\subsection{Model}

In order to examine the institutional determinants of $\mathrm{R} \& \mathrm{D}$ expenditure, the following model was devised.

$\ln \left(R \&\right.$ DIntensity $\left._{i t}\right)=\alpha_{i}+\beta_{1}\left(R \&\right.$ DIntensity $\left._{i, t-1}\right)+\beta_{2}\left(\right.$ GovernmentEffectiveness $\left._{i t}\right)+\beta_{3}\left(\right.$ RuleofLaw $\left._{i t}\right)+\beta_{4}\left(\right.$ Corruption $\left._{i t}\right)+$ $\beta_{5}\left(\right.$ PoliticalInstability $\left._{i t}\right)+\beta_{6}\left(\right.$ RegulatoryQuality $\left._{i t}\right)+\beta_{*}\left(\right.$ ControlVariables $\left._{i t}\right)+\eta_{i}+d_{t}+I_{i}+v_{i t}$

where subscript $i$ represents the firm and $t$ represents the year. R\&D intensity is considered as a dependent variable which, following Xiao (2013), takes the natural logarithm of one plus annual R\&D expenditure over sales. The main independent variables are government effectiveness, rule of law, corruption, political instability and regulatory quality. Firm, industry and macroeconomic variables are controlled, such as firm size, cash flow, debt ratio, industry dummy and GDP growth. The error component $\varepsilon_{i t}$ is separated into four subcomponents: $\varepsilon_{i t}=\eta_{i}+\mathrm{d}_{t}+\mathrm{I}_{i}+\mathrm{v}_{i t} . \eta_{i}$ is considered as an individual effect to control for individual heterogeneity, which is then eliminated by taking first differences. In addition, the time dummy, denoted by $\mathrm{d}_{t}$, captures the time-specific effect to control for macroeconomic variables. As the industries are separated into technology and non-technology intensive, industry dummy $\mathrm{I}_{i}$ is included to capture industry-specific effects. Moreover, $\mathrm{v}_{i t}$ is considered as a random disturbance term, which is assumed to be i.i.d normal.

\subsection{Method}

In order to examine the institutional determinants of $R \& D$ spending in emerging countries, a Generalized Method of Moments (GMM) estimation was performed, following Hiller et al. (2011). This study used a GMM approach for several reasons. First, GMM approach is consistent with the panel data structure and it is efficient when less time periods (T equals 8) 
and more cross sections (N equals 664) (Asongu et al., 2018). Second, it was used to control for the endogeneity problem (Hillier et al., 2011). Some explanatory variables in the model are endogenous, which may create a problem of endogeneity. For example, firm size and R\&D investment causality may run in both directions-from firm size to $R \& D$ investment and vice versa. Firm size may impact on $R \& D$ investment as greater availability of resources may encourage managers to commence new R\&D activities (Pindado et al., 2015). On the other hand, investment in $R \& D$ activities increase firm performance by increasing the quality as well as quantity of the product that are produced and sold, which results in expand the firm operation. Endogeneity problem may also arise due to omitted variable bias and measurement errors (Teixeira and Queirós, 2016). Third, strategic investments such as R\&D follow the path-dependent hypothesis (Garcia-Quevedo et al., 2014), and cumulativeness of information and knowledge implies that the current year's R\&D investment follows that of the previous year. Therefore, use of lagged values of dependent variables as instruments may produce biased results. However, GMM estimations control for lagged values of the dependent variable (David et al., 2006). Fourth, both heteroscedasticity and auto-correlation problems can be addressed by GMM estimations (David et al., 2006). Heteroscedasticity may arise because different countries in the sample have different characteristics, thus the residuals are unlikely to be constant across observations. Using the lag of dependent variables may create auto-correlation problems. Fifth, according to Hansen (1982), GMM estimations provide a general framework within which to take into account issues of statistical inference, as they encompass many estimators of interest to econometrics. In this regard, Worrall (2008) stated that, within a single framework, GMM nests several estimations, such as OLS, 2SLS and IV. Finally, previous researchers (e.g. Hillier et al., 2011; Pindado et al., 2015; Asongu et al., 2018) also have applied GMM estimation to similar research. 
There are two forms of GMM estimation: system GMM and difference GMM. As our panels are unbalanced, it is better to use system GMM and avoid difference GMM, which has weakness of magnifying gaps (Roodman, 2009; Uddin et al., 2017). Moreover, panel unit root tests leads us to choose system GMM as both sets of moment conditions (first difference and level equation) were considered. Table 4 presents the panel unit root tests. Among the existing number of methods such as Levin-Lin-Chu (LLC) tests, Harris-Tsavalis tests, Breitung tests, and Fisher-type tests, later unit root tests based on augmented dickey-fuller (ADF) were chosen as it allows unbalanced panel data. The null hypothesis of Fisher-type test is that panels contain unit roots (i. e. the variables are non-stationary). The results shows that R\&D intensity, rule of law, regularity quality, size, cash flow, and GDP growth are stationary at level while after first-order differencing government effectiveness, corruption and political instability become stationary. The results confirmed that variables in our model are stationary which also hold the assumption of system GMM. Lee and Azali (2010) and Perera and Lee (2013) pointed that if not all variables are stationary in the levels equations as in our case, the difference GMM would not be efficient. Moreover, Binder et al. (2005) and Ulku (2005) stated that unlike difference GMM, system GMM estimators continue to be consistent even the variables are non-stationary.

Table 4: Panel unit root tests

\begin{tabular}{lll}
\hline \hline & Level & First difference \\
\hline R\&D intensity & $68.9632^{* * *}$ & \\
Government effectiveness & -12.9183 & $16.2070^{* * *}$ \\
Rule of law & $2.9366^{* *}$ & \\
Corruption & -2.4997 & $162.3577^{* * *}$ \\
Political instability & -1.1905 & $170.0380^{* * *}$ \\
Regularity quality & & \\
Firm size & $7.6808^{* * *}$ & \\
\end{tabular}




Cash flow
Debt ratio
\begin{tabular}{l}
$58.9561^{* * *}$ \\
GDP growth \\
\hline \hline
\end{tabular}
$\begin{aligned} & \text { Notes: All panel unit root tests were performed with intercept and trend for all variables. } \\
& \text { Level of significant: } *<.10, * *<.05, * * *<.01\end{aligned}$

In comparison to other estimations such as difference GMM, ordinary least square (OLS), and within-groups estimator, system GMM provides efficient and consistent estimation. System GMM has been found to be more efficient than difference GMM (Blundell and Bond, 1998), while difference GMM estimation has a problem of weak instruments (AlonsoBorrego and Arellano, 1999). Due to weak instruments, difference estimator coefficient on lagged dependent variable are biased downward (Bond et al., 2001; Hillier et al., 2011). In a similar vein, OLS estimates of the coefficient on lagged dependent variable are biased upward as it does not control for unobserved heterogeneity (Hsiao, 1986; Hillier et al., 2011) while within-groups estimates of the coefficient on lagged dependent variable are biased downward as it does not control for endogeneity problem (Nickell, 1981; Hillier et al., 2011).

The reliability and consistency of the system GMM estimation depends on the validity of the instruments. We applied several tests for the validity of our instruments. The first test is the Hansen $\mathbf{J}$ statistic of over-identifying restrictions, which test the overall validity of the instruments. Hansen $\mathbf{J}$ test results show that the instruments are valid in the model. The second test is the difference-in-Hansen test of exogeneity, which shows that the subset of instruments was used for the equations in levels is exogenous. The third test is that secondorder autocorrelation $\mathrm{AR}(2)$ in the first difference residuals unable to reject the null hypothesis suggests the presence of no autocorrelation. The fourth is that the number of instruments should not be higher than the number of groups (Tsekouras et al., 2016). In this case, the test results show that the number of instruments is far lower than the number of 
groups. These results provide confidence that the instruments used are strong enough for GMM estimation.

Two Wald tests were also used to examine whether the independent variables are jointly equal to zero: $z_{1}$ is a test of the joint significance of the regressors, and $z_{2}$ is a test of the joint significance of the time dummies, suggesting that aggregate factors exert a significant influence on the relationship between $R \& D$ investment and the explanatory variables. The two Wald tests provided satisfactory results for the model. Moreover, to fix the possible downward bias of standard errors, the Windmeijer (2005) finite-sample corrected two-step covariance matrix was applied.

\section{Results \& Discussion}

The Table 5 presents the empirical results of the GMM estimation. In line with the expectation, government effectiveness, rule of law, corruption, political instability, and regularity quality has significant impact on $R \& D$ expenditure in the emerging countries. Thus, the results support the institutional based view. Moreover, the results show that firm size, debt ratio and cash flow also influence $R \& D$ investment considerably. The results clearly show that R\&D investment is not only sensitive to internal factors but also adequately sensitive to institutional environment such as social, legal and political factors. In a recent study, Cui et al. (2016) also reached at similar findings based on data from emerging economies such as Brazil, Russia, India, China, and South Africa (BRICS) and concluded that institutional settings have significant impact on firm's technological innovation. 
Table 5: Results Summary - GMM Estimation

\begin{tabular}{ll}
\hline \hline & \\
R\&D intensity ${ }_{t-1}$ & $0.70499^{* * *}$ \\
& $(0.07815)$ \\
Government effectiveness & $0.00153^{*}$ \\
Rule of law & $(0.00088)$ \\
& $0.00140^{*}$ \\
Corruption & $(0.00074)$ \\
Political instability & $-0.00213^{*}$ \\
& $(0.00110)$ \\
Regularity quality & $-0.00096^{* *}$ \\
\end{tabular}




\begin{tabular}{|c|c|}
\hline & $(0.00105)$ \\
\hline \multirow[t]{2}{*}{ Size } & $0.00062^{*}$ \\
\hline & $(0.00032)$ \\
\hline \multirow[t]{2}{*}{ Cash flow } & $-0.00015^{* * *}$ \\
\hline & $(0.00003)$ \\
\hline \multirow[t]{2}{*}{ Cash flow $_{t-1}$} & $0.00008^{*}$ \\
\hline & $(0.00004)$ \\
\hline \multirow[t]{2}{*}{ Debt ratio } & $-0.00290 * *$ \\
\hline & $(0.00143)$ \\
\hline \multirow[t]{2}{*}{ GDP growth } & 0.00003 \\
\hline & $(0.00004)$ \\
\hline Industry dummies & Yes \\
\hline Year dummies & Yes \\
\hline Total observations & 3938 \\
\hline Number of groups & 664 \\
\hline Number of instruments & 218 \\
\hline $\mathrm{AR}(1)$ & -2.73 \\
\hline$P$-value & 0.006 \\
\hline $\operatorname{AR}(2)$ & 0.51 \\
\hline$P$-value & 0.611 \\
\hline$z_{1}$ & $69.99(12)$ \\
\hline$P$-value & 0.0000 \\
\hline$z_{2}$ & $1.84(5)$ \\
\hline$P$-value & 0.091 \\
\hline Hansen J test & 244.48(197) \\
\hline$P$-value & 0.102 \\
\hline Diff-in-Hansen & $123.03(62)$ \\
\hline$P$-value & 0.118 \\
\hline
\end{tabular}

Standard errors in parenthesis. Level of significant: $*<.10, * *<.05, * * *<.01$

It is evident from Table 5 that lagged value of the dependent variable is significantly different from zero, showing the persistency of R\&D investment. Persistence rate of 70.50 percentages suggests that firms follow a stable R\&D policy in the emerging markets. García-Quevedo et al. (2014) reached to the same conclusion based on path-dependent hypothesis. The study has found that government effectiveness has positive influences on $R \& D$ investment in the selected emerging countries. A change in government effectiveness by one unit is associated with a 0.15 percentage change in firms' $R \& D$ expenditure. It is evident from our result that effective government creates favourable environment for R\&D investment of a country by facilitating access to finance and easy market entry, by attracting more investment and in 
particular by accelerating technological investment. Jiao et al. (2015) also suggested the same and stated that firms perform better in innovation when government effectiveness is higher than firms without such an environment. Thus, the results support the hypothesis 1 . The study has also found a significant positive relation between legal system and R\&D investment among the selected countries. With a one-unit change in legal system, the likelihood of R\&D investment increases by 0.14 percent. This implies that strong legal systems attract investors and increase investor confidence in R\&D. In this regard, Jiao et al. (2015) added that a good legal environment not only increases firms' R\&D investment but also improves the efficiency of technological innovation, which increases the number of patent applications. Similar to our finding, Hiller et al. (2011), Jiao et al. (2015), and Seitz and Watzinger (2017) also concluded that strong legal system encourages $R \& D$ investment. Therefore, this result supports the hypothesis 2 .

This study has found a negative relationship between R\&D investment and corruption among the selected countries. With one-unit change in corruption, there is a probability of $R \& D$ expenditure decreasing by 0.21 percent. Mahagaonkar (2008) also found the negative relation between corruption and innovation. This is because corruption increase the investment cost and discourages the foreign investors. The results support the hypothesis 3 . This study also found a significant negative relationship between political instability and R\&D investment. Political environment significantly explains the R\&D investment by affecting uncertainty and cost associated with $\mathrm{R} \& \mathrm{D}$ investment. It has been found that one-unit deterioration in political condition decreases R\&D expenditure by 0.10 percent. Allard et al. (2012) obtained similar results. The results support the hypothesis 4 . Regulatory quality has been found to be another significant determinants of $R \& D$ investment in selected emerging countries. The study has found a significant positive relation between regulatory quality and $R \& D$ 
investment. More specifically, the study has found that one-unit change in regulatory standard increases $R \& D$ investment by 0.18 percent. This implies that high quality of government regulations ensure stable and consistent R\&D investment. Blind et al. (2017) also reached at similar conclusion. The results support the hypothesis 5 .

Firm size has a significant positive impact on R\&D investment. Larger firms will have better access to financial market and therefore less constrained to get required funds for making R\&D investments. Moreover, due to wider scope of diversification by the larger firms, internal financing source tend to be rich for larger firms. As a result, larger firms make more R\&D investments compared to the smaller firms. This study has found a strong positive relationship between firm size and $R \& D$ investment which is consistent with earlier findings such as Fishman and Rob (1999), Tsai and Wang (2004) and Lai et al. (2015). The study has also found a negative relation between debt and $R \& D$ investment. $R \& D$ projects are uncertain in nature with high degree of information asymmetry. These projects are also characterised by lack of collateral. As a result, it is quite difficult to finance these projects with debt. Our result is consistent with earlier findings such as Hall (1992), Hall (2002), Hottenrott and Peters (2012), and Lin et al. (2017).

This study has found a negative relation between current year cash flow and R\&D investment which is different from some of the earlier studies such as Hall (1992), Himmelberg and Petersen (1994), Brown and Petersen (2009), Brown et al. (2009), Hottenrott and Peters, (2012), and Sasidharan et al., (2015). Despite these positive R\&D-cash flow evidences, a negative relation is not very unusual. For example, Bhagat and Welch (1995), Seifert and Gonenc (2012), Li et al. (2015) and Podolski (2016) have found negative relationship between cash flow and $R \& D$ investment. One of the reasons for these differences in results could be due to the selection of different periods of time for testing the hypotheses or 
variations in model specifications employed for the analysis. For instance, Rapp and Udoieva (p.28, 2016) used different estimations such as OLS, Tobit, Heckman $1^{\text {st }}$ Step, Heckman $2^{\text {nd }}$ Step, and System GMM and found different relationship between cash flow and R\&D investment for the same sample. In addition, the negative relation can be an outcome of pecking order of the use of cash flow as suggested by Dasgupta et al. (2012). The authors have pointed out that any immediate increase in cash flow would be used to build cash stock and reduce leverage rather than using it for investments. Moreover, the adjustment cost hypothesis postulates that higher level of adjustment cost associated with R\&D investment may discourage managers from making R\&D investment (Himmelberg and Petersen, 1994; Sasaki, 2016). Although, this study has found a negative relationship between contemporaneous cash flow and $\mathrm{R} \& \mathrm{D}$ investment, a statistically significant positive relationship has been found between lagged value of cash flow and R\&D investment. This again laid support to adjustment cost hypothesis which states that due to the high adjustment costs related to $R \& D$ investment, firms tend not to make $R \& D$ investment based on contemporaneous cash flow rather firms depend on permanent increase in cash flow to make R\&D investment (Himmelberg and Petersen, 1994). Sasaki (2016) also pointed out that if the future outlook of cash flow is not promising then managers do not tend to make $R \& D$ investments. However, the author pointed out that if managers find out that the increase in cash flow is permanent in nature, then managers become encouraged to make $R \& D$ investment. Himmelberg and Petersen (1994) concluded that R\&D investment responds to changes in permanent cash flow rather than changes in transitional cash flow. Brown et al. (2009), Brown et al. (2012), and Sasaki (2016) have found evidence on the positive relationship between lagged value of cash flow and R\&D investment.

Although GDP growth is higher in emerging markets, contrary to the accelerated principle, it is uncorrelated with $\mathrm{R} \& \mathrm{D}$ expenditure. This is because emerging countries spend their 
income on infrastructural development. Moreover, the recent financial crisis adversely affected emerging countries. Based on a study of OECD countries, Wang (2010) also found GDP to be a fragile determinant of aggregate R\&D.

\section{Elasticity Test:}

Table 6 shows that elasticity test of the variables. Hillier et al., (2011) states that elasticity test gives the homogenous base for comparison. Therefore, following Hillier et al. (2011), we performed elasticity test to compare the explanatory power of the institutional variables for R\&D investment. We computed the elasticity based on the following formula:

$$
E_{i}=\beta_{i} \frac{\bar{X}_{i}}{\beta^{p} \overline{\mathrm{X}}}
$$

Where $I$ represents the institutional variables, $\beta_{i}$ indicates its coefficient, $\bar{X}_{i}$ is its mean, and $\beta^{p} \overline{\mathrm{X}}$ captures the predicted value of the dependent variable evaluated at the mean of each regressor.

The results show that among the institutional determinants, corruption $\left(E_{c}=-0.31716\right)$ has the highest explanatory power followed by regulatory quality $\left(E_{r q}=0.26148\right)$, government effectiveness $\left(E_{g e}=0.22786\right)$, rule of law $\left(E_{r l}=0.20838\right)$, and political instability $\left(E_{p i}=\right.$ 0.14343). This implies that long term and risky investment like $\mathrm{R} \& \mathrm{D}$, would be more influenced by the level of corruption in emerging markets. This is expected as R\&D is more of a long term investment and investment in a corrupt country surely indicates that the sufferings from that investment would be long term as well. Moreover, as we have mentioned earlier that corruption increases information asymmetry and cost of doing business, R\&D investors would surely be discouraged by the level of corruption in emerging markets. 


\begin{tabular}{lc}
\hline \hline Variables & Elasticity \\
\hline Government effectiveness & 0.22786 \\
Rule of law & 0.20838 \\
Corruption & -0.31716 \\
Political instability & -0.14343 \\
Regularity quality & 0.26148 \\
\hline \hline Source: Author's calculation & \\
\hline
\end{tabular}

\section{Robustness Test:}

The robustness of the results has been tested using Ordinary Least Square (OLS) ${ }^{5}$ estimation (see Table 7). In order to control for heteroscedasticity and autocorrelation, a cluster-robust standard error was used. The key results concerning institutional factors remain unchanged except for government effectiveness. In our robustness test, government effectiveness has a positive sign but became statistically insignificant. The results also show that rule of law and regularity quality are positively related to $R \& D$ investment, while corruption and political instability affect R\&D negatively in our selected emerging markets. It can be seen that the results are robust and fully support Hypotheses 2, 3, 4, and 5, while Hypotheses 1 is supported but not robustly. However, other variables retain the same sign.

\section{Table 7: Robustness Test}

$\begin{array}{ll}\text { R\&D intensity } t-1 & 0.86224^{* * *} \\ & (0.03406) \\ \text { Government effectiveness } & 0.00044 \\ \text { Rule of law } & (0.00097) \\ & 0.00099^{*} \\ \text { Corruption } & (0.00072) \\ & -0.00171^{*} \\ & (0.00094)\end{array}$

\footnotetext{
${ }^{5}$ We also conducted regression analysis by Tobit estimation. The results are the same as OLS. We also tested the multicollinearity among the variables. It is expected that institutional factors to be highly correlated one another due to their close connectedness and one could make judgements about the overall quality of a national institution (Tabellini, 2008). The pairwise correlations range is from 0.0141 to 0.9362 . The results will send upon request.
} 


\begin{tabular}{|c|c|}
\hline \multirow[t]{2}{*}{ Political instability } & $-0.00082 * *$ \\
\hline & (0.00037) \\
\hline \multirow[t]{2}{*}{ Regularity quality } & $0.00212^{*}$ \\
\hline & (0.00116) \\
\hline \multirow[t]{2}{*}{ Firm size } & 0.00008 \\
\hline & $(0.00020)$ \\
\hline \multirow[t]{2}{*}{ Cash flow } & $-0.00016^{* * *}$ \\
\hline & $(0.00004)$ \\
\hline \multirow[t]{2}{*}{ Cash flow $_{t-1}$} & $0.00013^{* * *}$ \\
\hline & $(0.00003)$ \\
\hline \multirow[t]{2}{*}{ Debt ratio } & $-0.00259 * *$ \\
\hline & $(0.00096)$ \\
\hline \multirow[t]{2}{*}{ GDP growth } & 0.00004 \\
\hline & $(0.00006)$ \\
\hline Industry dummies & Yes \\
\hline Time dummies & Yes \\
\hline R-squared & 0.8086 \\
\hline F test & $181.90(18)$ \\
\hline
\end{tabular}

\section{Conclusion}

$\mathrm{R} \& \mathrm{D}$ investment is considered to be one of the most essential elements in promoting economic growth and development (OECD, 2015). Therefore, it is important for countries in general and emerging markets in particular to continue making $R \& D$ investment. It has been argued that sound and strong institutions helps to promote $R \& D$ investment by ensuring better access to finance, less information asymmetry, mitigating the managerial expropriation problem and providing better investor protection and reducing transaction cost. Thus, $\mathrm{Wu}$ et al. (2016) pointed out that the institutional environment may impact R\&D activity by providing supports or constraints beyond the capacity of an individual firm. Good institutions are important to promote R\&D across the world but are more important for emerging markets as government and societal influences are much stronger in those economies (Hoskisson et al., 2000; Kang and Jiang, 2012). This study has examined the institutional determinants of R\&D expenditure using panel data from 20 emerging countries for the period 2006-2013. Using GMM estimation method, the study has found that a set of selected institutional factors 
have significant influence on the level of $R \& D$ investment in the selected emerging countries. More specifically, results show that government effectiveness, rule of law, and regularity quality have significant positive impacts, while corruption and political instability have significant negative impacts on $\mathrm{R} \& \mathrm{D}$ investment in emerging countries. Effective government and strong law and regulations of a country may stimulate R\&D investment by facilitating access to finance, ensuring market entry, attracting foreign investors, increasing investors' confidence and protection, and in particular by accelerating technological investment. On the other hand, the study has found that corruption and political instability have got negative impact on $\mathrm{R} \& \mathrm{D}$ investment. Corruption increases information asymmetry and the cost of R\&D investment and political instability may discourage both local and foreign investors to invest in $R \& D$ activities as they increase the risk and uncertainty of investment. The results are significant in alternative robustness checks. We also performed elasticity test to compare among the institutional factors. The results show that among the institutional determinants, corruption has the highest explanatory power followed by regulatory quality, government effectiveness, rule of law, and political instability.

The results of this study has important policy implications. A widely accepted view among the researchers and practitioners is that innovation is an important constituent of productivity, competitiveness and sustainable economic growth (Hottenrott and Peters, 2012). However, emerging markets are not being able to attract sufficient level of $R \& D$ investment commensurate with their growth prospect. Only few among the emerging markets are successful in promoting $R \& D$ investment and the rest are struggling to maintain the pace (Howells, 2008). To overcome the problem of underinvestment in $R \& D$, we have to be aware of various firm level and institutional determinants so that appropriate policy can be formulated to promote $R \& D$ investment. It has been argued that country level determinants like institutional factors are more important than firm level factors as institutions can explain 
larger aggregate trends from period to period whereas firm-level factors only explains some variance within the period (Pattit et al. 2012). Therefore, policy makers from emerging markets should focus more on institutional factors to formulate appropriate policy to enhance the $R \& D$ investment. It is pertinent to mention that focusing on institutional factors to formulate policies would be cost effective as Doidge et al. (2007) pointed out that for emerging economies, firm level factors explain almost nothing as the cost of adoption of those variables outweighs the benefits.

This research has shown the importance of the institutional environment for firms' decision making on R\&D investment. Due to missing values, some economic and cultural factors that might affect firm-level R\&D investment were not included in this study. In addition, due to missing values, not all emerging markets were included in the analysis. Moreover, primary data could have been used for more detail firm level analysis. Further investigation may be helpful on other emerging markets using data on firm level institutional factors to complement the results of this research.

Acknowledgement: This paper was presented in $7^{\text {th }}$ International Research Meeting in Business and Management - 2016 and White Rose Business and Management, Accounting and Finance and Work Psychology Pathway Annual conference - 2016. Thanks to the participants and discussants of these conferences. Authors are also indebted to Professor Julio Pindado for his valuable comments on the prior draft of this paper. We would also like to express our sincere thanks to the Editor and two anonymous reviewers for their helpful comments on earlier drafts of this paper. 


\section{References}

Acharya, V.V. and Subramanian, K.V. 2009. Bankruptcy codes and innovation, Rev. Fin. Stu., 22(12), 4949-4988.

Alam, A., Uddin, M. and Yazdifar, H. 2017. Financing behaviour of R\&D investment in the emerging markets: The role of alliance and financial system. R\&D Man., Forthcoming.

Allard, G., Martinez, C.A. and Williams, C., 2012. Political instability, pro-business market reforms and their impacts on national systems of innovation, Res. Pol., 41, 638-651.

Alonso-Borrego, C. and Arellano, M., 1999. Symmetrically normalnormalized instrumentalvariable estimation using panel data., J. Busi. Econ. Stat., 17(1), 36-49. 
Anderlini, L., Felli, L., Immordino, G. and Riboni, A., 2013. Legal institutions, innovation, and growth, Int. Econ. Rev., 54(3), 937-956.

Anokhin, S., and Schulze, W. S., 2009. Entrepreneurship, innovation, and corruption, J. Bus. Vent., 24 (5), 465-476.

Asongu, S. A., Nwachukwu, J. C., Orim, S.-M. I., 2018. Mobile phones, institutional quality and entrepreneurship in Sub-Saharan Africa. Tech. Fore. Soc. Chang.,131,183-203.

Atanassov, J., Julio, B. and Leng, T., 2016. The bright side of political uncertainty: The case of R\&D. Paper presented at FMA Asia/Pacific conference.

Barge-Gil, A. and López, A., 2014. R\&D determinants: Accounting for the differences between research and development, Res. Pol., 43(9), 1634-1648.

Bénassy-Quéré, A., Coupet, M. and Mayer, T., 2007. Institutional determinants of foreign direct investment, W. Econ., 30 (5), 764-782.

Bhagat, S. and Welch, I., 1995. Corporate research and development investments: International comparisons, J. Acc. Econ., 19(2-3), 443-470.

Binder, M. Hsiao, J. and Pesaran, M. H., 2005. Estimation and inference in short panel vector autoregressions with unit roots and cointegration, Econ. Theo., 21,795-837.

Blind, K., 2012. The influence of regulations on innovation: A quantitative assessment for OECD countries, Res. Pol., 41, 391-400.

Blind, K., Petersen, S. S.,and Riillo, C. A. F., 2017. The impact of standards and regulation on innovation in uncertain markets, Res. Pol., 46, 249-264.

Blundell, R. and Bond, S., 1998. Initial conditions and moment restrictions in dynamic panel data models, J. Econ., 87, 115-143.

Bond, S. Hoeffler, A. and Temple, J., 2001. GMM estimation of empirical growth models, Diss. P. No. 01/525, Uni. of Bristol.

Brown, J.R. and Petersen, B.C., 2009. Why has the investment-cash flow sensitivity declined so sharply? Rising R\&D and equity market developments, J. Bank. Fin, 33, 971-984.

Brown, J.R., Martinsson, G., and Petersen, B.C., 2012. Do financing constraints matter for R\&D, Euro. Econ. Rev.,56(8),1512-1529

Brown, J.R., Steven, M., Fazzari, S.M. and Petersen, B.C., 2009. Financial innovation and growth: Cash flow, external equity and 1990s R\&D boom, J. Fin., 64(1), 151-186.

Choi, Y.R., Yoshikawa, T., Zahra, S.A. and Han, B.H., 2014. Market-oriented institutional change and R\&D investments: Do business groups enhance advantage?, J. W. Bus., 49, 466 475. 
Cui, Y., Jiao, J. and Jiao, H., 2016. Technological innovation in Brazil, Russia, India, China, and South Africa BRICS: An organizational ecology perspective, Tech. Fore. Soc. Chang., 107, 28-36.

Dasgupta, S., Noe, T.H. and Wang, Z. 2011. Where did all the dollars go? The effect of cash flows on capital and asset structure., Journal of Financial and Quantitative Analysis, 46(5), 1259 - 1294.

Daude, C. and Stein, E., 2007. The quality of institutions and foreign direct investment, Eco. Pol., 19, 317-344.

David, P. Yoshikawa, T. Chari, M. D. R. and Rasheed, A. A., 2006. Strategic investment in Japanese corporations: Do foreign portfolio owners foster underinvestment or appropriate investment?, Str. Man. J., 27, 591-600.

Doidge, C., Karolyi, G.A. and Stulz, R. M. 2007. Why do countries matter so much for corporate governance? J. Fin. Econ., 86, 1 - 39.

Dolfsma, W. and Seo, D., 2013. Government policy and technological innovation- a suggested typology, Tech., 33, 173-179.

Dosi, G., Pavitt, K. and Soete, L., 1990. The economics of technical change and international trade, Brighton: Wheatsheaf.

Dunning, J. H., 2006. Towards a new paradigm of development: Implications for the determinants of international business, Trans. Corp., 15(1), 173-227.

Edquist, C. and Johnson, B., 1997. Systems of innovation: Technologies, institutions and organizations, London: Rouetledge.

Fishman, A. and Rob, R., 1999. The size of the firms and R\&D investment, Int. Econ. Rev.,40(4),915-931

Flannery, M., and Hankins, K. W., 2013. Estimating dynamic panels in corporate finance, J. Corp. Fin.,19, 1-19.

Freeman, C., 1987. Technology policy and economic performance: Lessons from Japan, London: Pinter.

Furukawa, Y., 2007. The protection of intellectual property rights and endogenous growth: Is stronger always better?, J. Econ. Dyn. Cont., 31(11), 3644-3670.

García-Quevedo, J., Pellegrino, G. and Vivarelli, M., 2014. R\&D drivers and age: Are young firms different?, Res. Pol., 43(9), 1544-1556.

Ghosh, C. and He, F., 2015. Investor protection, investment efficiency and value: The case of cross-listed firms, Fin. Man., 44(3), 499-546. 
Grabowski, H., 1968. The determinants of industrial research and development: A study of the chemical, drug, and petroleum industries, J. Pol. Econ., 76(2), 292-306.

Hall, B.H., 2002. The financing of research and development, Oxf. Rev. Econ. Pol., 18(1), 35 -51 .

Hall, B.H., 1992. Investment and research and development at the firm level: Does the source of financing matter?, NBER W. P.-4096.

Hansen, L. P., 1982. Large sample properties of generalized method of moments estimators, Econ., 50, 1029-1054.

Hashi, I. and Stojcic, N., 2013. The impact of innovation actvities on firm performance using a multi-stage model: Evidence from the community innovation survey 4, Res. Pol., 42, 353366.

Henisz, W., 2002. The institutional environment for infrastructure investment, Ind. Corp. Chang., 11(2), 355-389.

Hillier, D., Pindado, J., Queiroz, V.d. and Torre, C.d.1., 2011. The impact of country-level corporate governance on research and development, J. Int. Bus. Stud., 42, 76-98.

Himmelberg, C.P. and Petersen, B.C., 1994. R\&D and internal finance: A panel study of small firms in high-tech industries', Rev. Econ. Stat., 76(1), 38-51.

Hong, J., Wang, C. and Kafouros, M., 2015. The role of the state in explaining the internationalization of emerging market enterprises, Brit. J. Man., 26, 45-62.

Hoskisson, R. E., Eden, L., Lau, C. M. and Wright, M. 2000. Strategy in emerging economies. Acad. Man. J., 43, 249-267.

Hottenrott, H. and Peters, B. 2012. Innovative capability and financing constraints for innovation: More money, more innovation? Rev. Econ. Stat., 94(4), 1126 - 1142.

Howells, J. 2008. New direction in R\&D: Current and prospective challenges. R\&D Man., $38(3), 241-252$.

Hsiao, C., 1986. Analysis of panel data, Cambridge: Cam. Uni. Press.

IFC, 2002. Developing value: The business case for sustainability in emerging markets, $1^{\text {st }}$ edi., W. B. G. Pub.

Jalilian, H., Kirkpatrick, C. and Parker, D., 2007. The impact of regulation on economic growth in developing countries: A cross-country analysis, W. Dev., 35(1), 87-103.

Javorcik, B.S. and Wei, S-J., 2009. Corruption and cross-border investment in emerging markets: Firm-level evidence, J. Int. Mon. Fin., 28, 605 - 624. 
Jiao, H., Koo, C.K. and Cui, Y., 2015. Legal environment, government effectiveness and firms innovation in China: Examining the moderating influence of government ownership, Tech. Fore. Soc. Chang., 96, 15-24.

Julio, B. and Yook, Y., 2012. Political uncertainty and corporate investment cycle, J. Fin., $67(1), 45-83$.

Kafouros, M. and Aliyev, M. 2016. Institutional development and firm profitability in transition economics, J. W. Bus., 51, 369-378.

Kallunki, J.-P., Pyykko, E. and Laamanen, T., 2009. Stock market valuation, profitability and R\&D spending of the Firm: The effect of technology mergers and acquisions, J. Bus. Fin. Acc., 36(7), 838-862.

Kang, Y. and Jiang, F., 2012. FDI location choice of Chinese multinationals in East and Southeast Asia: Traditional economic factors and institutional perspective, J. W. Bus., 47, 4553.

Kaufmann, D., Kraay, A. and Mastruzzi, M., 2009. Governance matters VIII: Aggregate and individual governance indicators, 1996-2008, W. B. Pol. Res. W. P.- 4978.

Kaufmann, D., Kraay, A. and Mastruzzi, M., 2010. The worldwide governance indicators: Methodogy and analytical issues, W. B. Pol. Res. W. P.- 5430.

Kirkpatrick, C., Parker, D. and Zhang, Y.-F., 2006. Foreign direct investment in infrastructure: Does regulation make a difference?, Trans. Corp., 15(1), 143-171.

Klomp, J. and Haan, J., 2009. Political institutions and economic volatility, Euro. J. Pol. Econ., 25, $311-326$.

Krammer, S.M.S., 2009. Drivers of national innovation in transition: Evidence from a panel of Eastern European countries, Res. Pol., 38(5), 845-860.

Krammer, S.M.S., 2015. Do good institutions enhance the effect of technological spillovers on productivity? Comparative evidence from developed and transition economies, Tech. For. Soc. Chang., 94, 133-154.

La Porta, R., Lopez-de-Silanes, F., Shleifer, A. and Vishny, R., 1997. Legal determinants of external finance, J. Fin, 52(3), 1131-1150.

Laeven, L., 2003. Does financial liberalisation reduce financing constraints?, Fin. Man., Sp., 5-34.

Lai, Y.-L., Lin, F.-J. and Lin, Y.-H., 2015. Factors affecting firms R\&D investment decisions, J. Bus. Res., 68, 840-844.

Lall, S., 1983. Determinants of R\&D in LDC: The Indian engineering industry, Econ. Let., 13, (4), 379-383. 
Lederman, D. and Maloney, W.F., 2003. R\&D and development, Pol. Res. W. P.-3024.

Lee, G. H. Y. and Azali, M., 2010. The endogeneity of the optimum currency area criteria in East Asia, Econ. Mod., 27, 165-170.

Lewellyn, K.B. and Bao, S., 2015. R\&D investment, attainment discrepancies and national culture: A multilevel analysis, J. Int. Man., 21(1), 1-17.

Li, D., Magud, N.E., and Valencia, F., 2015. Corporate investment in emerging markets: Financing vs. real option channel, IMF W.P.-WP/15/285.

Li, J. and Kozhikode, R. K., 2009. Developing new innovation models: Shifts in the innovation landscapes in emerging economics and implications for global R\&D management, J. Int. Man., 15, 328-339.

Lin, Z. J., Liu, S., and Sun, F., 2017. The impact of financing constraints and agency costs on corporate R\&D investment: Evidence from China, Int. Rev. Fin., 17, 3-42

Logue, A.C., 2011. Emerging markets for dummies, Wiley Pub. Lnc.

Lundvall, B.A., 1992. National system of innovation: Towards a theory of innovation and interactive learning, London: Pinter.

Mahagaonkar P., 2008. Corruption and innovation: A grease or sand relationship?, Jen. Econ. Res. Pol.- 2008-017.

Mahendra, E., Zuhdi, U. and Muyanto, R., 2015. Determinants of firm innovation in Indonesia: The role of institutions and access to finance, TMCD W. P. : TMD-WP-64.

Mahmood, I., Chung, C.N. and Mitchell, W., 2012. The evolving impact of combinatorial opportunities and exhaustion on innovation by business groups as market development increases: The case of Taiwan, Man. Sci., 59, 1142 - 1161.

Mahmood, I. P. and Rufin, C., 2005. Governments dilemma: The role of government in imitation and innovation, Acad. Man. Rev., 30(2), 338-360.

Masino, S., 2015. Macroeconomic volatility, institutional instability and incentive to innovate, Rev. Dev. Econ., 19(1), 116 - 131.

Meyer, K.E., Estrin, S., Bhaumik, S.K. and Peng, M.W., 2009. Institutions, resources and entry strategies in emerging economies, Strat. Man. J., 30, 61-80.

Mobarak, A., 2005. Democracy, volatility and economic development, Rev. Econ. Stat. 87, $348-361$.

Nickell, S., 1981. Biases in dynamic models with fixed effects, Econ., 49, 1417-1426. 
North, D.C., 1990. Institutions, institutional change, and economic performance:, Cambridge, Massachusetts: Harvard Uni. Press.

OECD, 2015. The innovation imperative: Contributing to productivity, growth and wellbeing.

Oliver, R. L., 1997. Satisfaction: A behavioural perspective on the customer, Singapore: McGraw-Hill.

Parker, D., 1999. Regulation of privatised public utilities in the UK: Performance and governance, Int. J. Pub. Sec. Man., 12(3), 213-235.

Patra, S. K. and Krishna, V. V., 2015. Globalization of R\&D and open innovation: Linkages of foreign R\&D centers in India, J. O. Inn.: Tech. M. Com.,1:7,1-24.

Pattit, J.M., Raj, S.P. and Wilemon, 2012. An institutional theory investigation of US technology development trends since the mid-19 ${ }^{\text {th }}$ century, Res. Pol., 41, 306-318.

Pearce, J.L., Xin, K.M., Xu, Q.J. and Rao, A.N., 2011. Managers context: How government capability affects managers, Brit. J. Man., 22, 500-516.

Peng, M.W., Wang, D.Y.L. and Jiang, Y., 2008. An institutional-based view of international business strategy:A focus on emerging economies, J. Int. Bus. Stu., 39(5), 920-936.

Perera, L. D. H. and Lee G. H. Y., 2013. Have economic growth and institutional quality contributed to poverty and inequality reduction in Asia?, J. Asia. Econ., 27,71-86.

Phylaktis, K., 2009. Emerging markets finance: Overview of the special issue, J. Int. Mon. Fin., 28, 549-553.

Pindado, J. Requejo, I., and Rivera, J. C., 2017. Economic forecast and corporate leverage choices: The role of institutional environment, Int. Rev. Econ. Fin., 51, 121-144.

Pindado, J., Queiroz, V.d. and Torre, C.d.1., 2015. How do country-level governance characteristics impact the relationship between R\&D and firm value?, R\&D Man., 45(5), 515-526.

Podolski, E. J., 2016. Free cash flow and R\&D productivity, Available at SSRN: https://ssrn.com/abstract=2564308 or http://dx.doi.org/10.2139/ssrn.2564308

Priem, R.L. and Butler, J.E., 2001. Is the resource-based theory a useful perspective for strategic management research?, Acad. Man. Rev., 26(1), 22-40.

Rapp, M. S. and Udoieva, I., 2016. Corporate governance and its impact on R\&D investment in emerging markets, HHL Res. P. S. Cor. Gov.-14

Rodriguez, P., Uhlenbruck, K. and Eden, L. 2005. Government corruption and the entry strategies of multinationals. Acad. Man. Rev., 30 (2), 383-396. 
Romer, P., 1994. New goods, old theory, and the welfare costs of trade restrictions, J. Dev. Econ., 43, 5-38.

Roodman, D., 2009. A note on the theme of too many instruments. Oxf. Bull. Econ. Stat., 71, 135-158.

Sasaki, T., 2016. Financial cash flows and research and development investment, Pac.-Bas. Fin. J., 39, 1-15.

Sasidharan, S., Lukose, P. J. J., and Komera, S., 2015. Financing constraints and investments in R\&D: Evidence from Indian manufacturing firms, Quart. Rev. Econ. Fin.,55, 28-39

Scott, W.R., 1995. Institutions and organizations: Ideas, interests and identities., Thousand Oaks: Sage.

Seifert, B. and Gonenc, H. 2012. Creditor right and R\&D expenditure, Corp. Gov.: A. Int. Rev., 20(1), 3 - 20.

Seitz, M. and Watzinger, M., 2017. Contract enforcement and R\&D investment, Res. Pol., 46(1), 182-195.

Srholec, M., 2011. A multilevel analysis of innovation in developing countries, Ind. Corp. Chang., 20(6), 1539-1569.

Szczygielski, K., Grabowski, W., Pamukcu, M. T., and Tandogan, V. S., 2017. Does government support for private innovation matter? Firm-level evidence from two catching-up countries, Res. Pol., 46, 219-237.

Tabellini, G., 2008. Institutions and culture, J. Euro. Econ. Asso., 6, 255-294.

Tabrizi, B. N., 2005. Accelerating transformation: Process innovation in the global information technology industry, F. edi., Universal.

Teixeira, A. A. C. and Queirós, A. S. S., 2016. Economic growth, human capital and structural change: A dynamic panel data analysis, Res. Pol., 45, 1636-1648

Tsai, K. H. and Wang J. C., 2004. The R\&D performance in Taiwan's electrical industry: A longitudinal examination, R\&D Man.,34(2),179-189

Tsang, E.W.K., Yip, P.S.L. and Toh, M.H., 2008. The impact of R\&D on value added for domestic and foreign firms in a newly industrialized economy, Int. Bus. Rev., 17, 423-441.

Tsekouras, K. Chatzistamoulou, N. Kounetas, K. and Broadstock, D. C., 2016. Spillovers, path dependence and the productive performance of European transportation sectors in the presence of technology heterogeneity, Tech. For. Soc. Chang., 102, 261-274.

Uddin, M. A., Ali, M. H., Masih, M., 2017. Political stability and growth: An application of dynamic GMM and quantile regression, Econ. Mod., 64, 610-625. 
Ulku, H., 2005. R\&D innovation and growth: Evidence from four manufacturing sectors in OECD countries, Dev. Econ. Pub. Pol. W. P. N.-12, Uni. Of Manchester.

Varsakelis, N.C., 2006. Education, political institutions and innovation actvity: A crosscountry empirical investigation, Res. Pol., 35, 1083-1090.

Waarden, F.V., 2001. Institutions and innovation: The legal environment of innovating firm, Org. Stud., 22(5), 765-795.

Wan, W.P. and Hoskisson, R.E., 2003. Home country environments, corporate diversification strategies, and firm performance, Acad. Man. J., 46(1), 27-45.

Wang, C., Yi, J., Kafouros, M. and Yan, Y., 2015. Under what institutional conditions do business groups enhance innovation performance?, J. Bus. Res., 68, 694-702.

Wang, E.C., 2010. Determinants of R\&D investment: The extreme-bounds analysis approach applied to 26 OECD countries, Res. Pol., 39, 103-116.

Windmeijer, F., 2005. A finite sample correction for the variance of linear efficient two-step gmm estimators, J. Econ., 126(1), 25-51.

Worrall, J. L., 2008. The effects of local law enforcement block grants on serious crime, Crim. Pub. Pol., 7,325-350.

Wu, J., Wang, C., Hong, J., Piperopoulos, P. and Zhuo, S., 2016. Internationalization and innovation performance of emerging market enterprises: The role of host-country institutional development, J. W. Bus., 51, 251-263.

Xiao, G., 2013. Legal shareholder protection and corporate R\&D investment, J. Corp. Fin., 23, 240-266.

Yi, J., Wang, C. and Kafouros, M., 2013. The effects of innovative capabilities on exporting: Do institutional forces matter?, Int. Bus. Rev., 22, 392-406. 